\title{
Analysis of Socio-Culture for the Use of Instagram among Students
}

\author{
Indy Fungsihana,1,", Khalida Izdihar Rasyidaa,2, Kiki Rizki Amalinda ${ }^{a, 3}$, Ni’matu Rohmaha,4, \\ Kusumadyahdewi ${ }^{\mathrm{b}, 5}$ \\ ${ }^{a}$ Department of Electrical Engineering, State University of Malang, Malang, Indonesia \\ ${ }^{\mathrm{b}}$ State Islamic University of Maulana Malik Ibrahim Malang, Malang, Indonesia \\ 1 ifungsihan@gmail.com; ${ }^{2}$ khalida12051@ gmail.com; ${ }^{3}$ kikirizkiamalinda@gmail.com; ${ }^{4}$ nimaturohmah97@gmail.com; ${ }^{5}$ \\ kusumadyahdewi@pips.uin-malang.ac.id
}

\begin{tabular}{|c|c|}
\hline Article Info & ABSTRACT \\
\hline $\begin{array}{l}\text { Article history: } \\
\text { Received: March 4, } 2019 \\
\text { Revised: April 5, } 2019 \\
\text { Accepted: April 20, } 2019\end{array}$ & $\begin{array}{l}\text { The use of Instagram from only sharing photos or videos and interacting with users } \\
\text { has become a place for personal branding such as business events, information sources, } \\
\text { and publications to get appreciation. Among students, the purpose of using Instagram } \\
\text { can also change from the purpose of initial account creation. Different goals can be } \\
\text { influenced by the needs and suitability of media content. To examine the socio-culture } \\
\text { of Instagram usage patterns among students, research was conducted using a data } \\
\text { collection method using a questionnaire. The results show the suitability of content and } \\
\text { objectives do not affect the intensity of use, but affect the intensity of data upload. } \\
\text { Appropriateness of content affects the choice of Instagram users to take advantage of } \\
\text { privacy features. Based on these two things, it can be concluded that the intensity and } \\
\text { use of privacy features affect personal branding, because the intensity of the influence } \\
\text { of the level of communication of users with the audience, while the use of privacy } \\
\text { features will affect the level of audience curiositv towards user data. }\end{array}$ \\
\hline
\end{tabular}

\section{INTRODUCTION}

Instagram is an Android-based mobile application that serves to retrieve, edit, share photos and short videos to internet users[1]. Instagram ranked 4th as the most popular social media used in Indonesia in 2017.

Based on the results of a global web index survey on internet users in Indonesia, in the age range of 16-64 years, the first rank is Youtube with a usage percentage of $43 \%$, second rank Facebook with a usage percentage of $41 \%$, third rank Whatsapp with $40 \%$ usage percentage and fourth place Instagram with a percentage of 38\% (We Are Social, 2018). In addition, Instagram has the features of chat, video calls, likes and comments that function to interact between Instagram users.

Lately, Instagram has changed its function from initially only sharing photos or videos and interacting between users [2] to become a place for business events, a source of information, as a means of publicizing works to gain appreciation from many people, and even as a means of politics and propaganda [3][4]. Now there are many Instagram accounts that post various things, both of which will have a positive or negative impact on users.

As stated in the Dramaturgy concept by Ervin Goffman that individuals will compete to present themselves as possible. Goffman assumes when people interact they want to present a self-image that others will receive[5][6]. This effort is referred to as impression management. Each individual in fact does a construction on himself by presenting himself. So that the identity that appears is the depiction of what actually becomes the desire to fulfill social recognition needs [7].

In the uses and gratifications theory, it is emphasized that the audience is active in determining which media should be chosen to meet their needs[8]. The existence of media institutions as a source of information is no longer dominant, but it is the audience that moves the mass media to fulfill their needs or interests. In this viewpoint, it means that the audience 
has personal authority to determine the type of consumption of the media that is used to satisfy their needs [2][9].

Social behavior of Instagram users among students can also change from the purpose of initial account creation. Changes in student behavior can be influenced by the needs and desires of users in managing accounts and the impact felt when using Instagram[6]. So that many accounts are not active in posting and are only used as a means of searching for information, but many accounts are always active in sharing things. The study of this article examines the socio-cultural pattern of using Instagram among students.

\section{METHOD}

The stages of this research start from problem identification, objectives, problem constraints, literature studies, questionnaire design, questionnaire distribution, analysis of questionnaire results, and conclusions. This method is carried out without repetition of the process. The emergence of a new phenomenon of users of Instagram social networks is no longer utilizing as a medium of communication and sharing of visual works, but rather leads to the use of Instagram as an effective media personal branding[3][10].

Data obtained from questionnaire answers. Questionnaires were distributed to students domiciled in Malang online through Google Form. Variables used in research relate to the style of using Instagram. Questions asked can be categorized as the purpose of use, suitability of objectives with content, intensity of use, and use of privacy features. This research was conducted for one semester (3 months), starting from August to October 2018. Data will be processed to find out the results of the data, summarize the results of the questionnaire answers, and check the validity of the variables used. To find out the results of the questionnaire answers, the data will be processed in the form of bar charts.

\section{RESULT AND DISCUSSION}

The results of distributing questionnaires regarding the socio-cultural analysis of Instagram usage among students, were obtained by 72 respondents with 7 supporting attributes. Data will be analyzed and grouped, to see the different patterns of usage of Instagram.

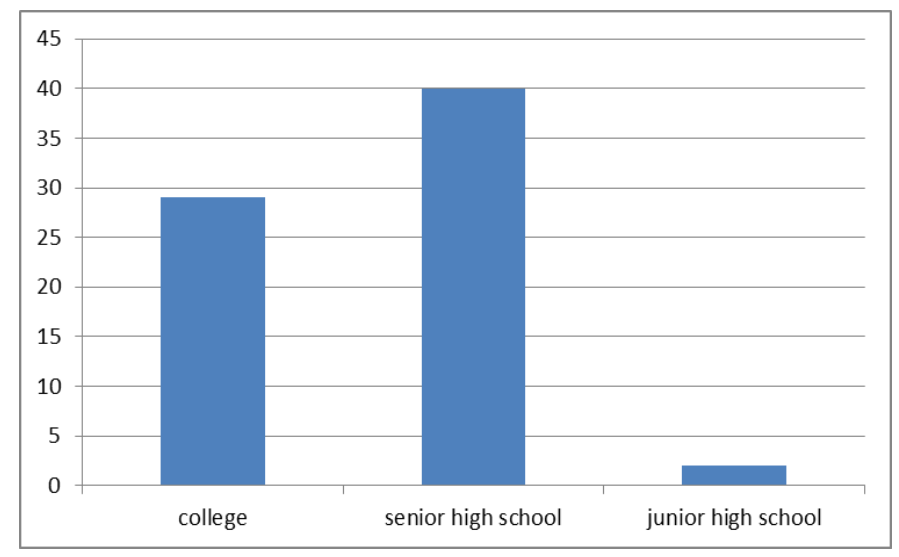

Fig. 1. Start using Instagram
Figure 1 shows the number of respondents categorized based on the initial use of Instagram. From Figure 1, there are more respondents who started using Instagram since high school, second place using Instagram starting college, and third place using Instagram starting junior high school. Based on Figure 1, it can be concluded that the majority of respondents began to use the age-range Instagram which was considered to be responsible for its use.

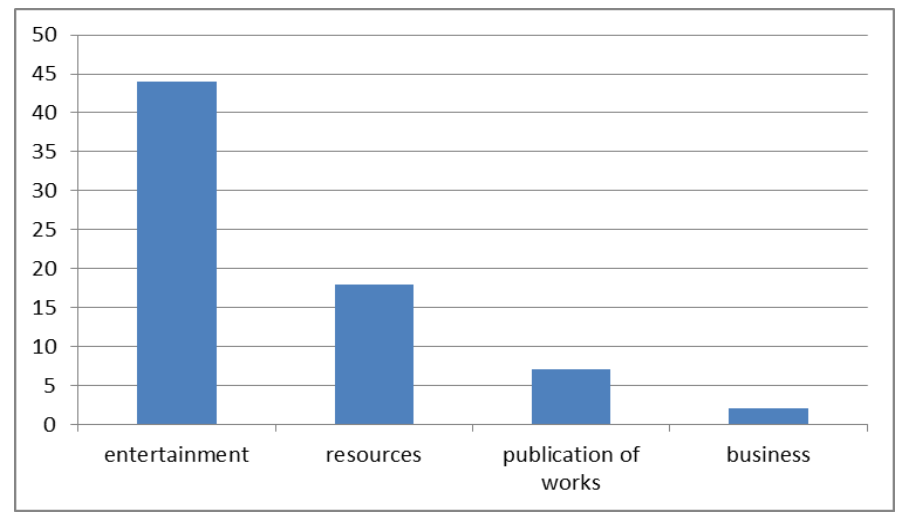

Fig. 2. The purpose of using Instagram

Figure 2 shows the number of respondents categorized based on the purpose of using Instagram. From Figure 2, it can be seen that most respondents use Instagram as an entertainment medium. This can be seen from the higher entertainment diagrams compared to information source diagrams, work publications, and businesses. The use of Instagram as a media for information resources is in the second place, followed by Instagram as a media for publishing works, and closed with Instagram as a business medium. Based on Figure 2, it can be concluded that Instagram, which is a photo and video sharing application, is used more by students as an entertainment medium than as a source of information, work publications, or business media.

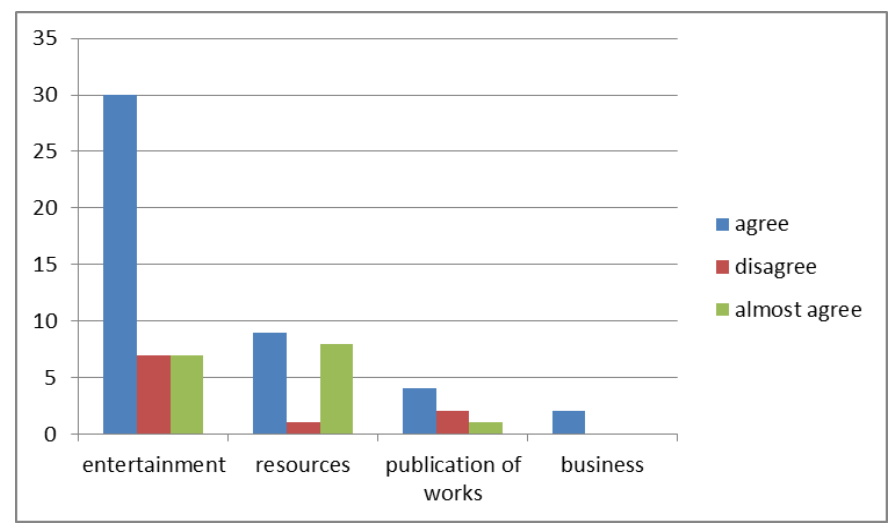

Fig. 3. Conformity of content and purpose

Figure 3 is a bar chart that shows the number of respondents who feel the Instagram content is appropriate, inappropriate, or almost in accordance with the purpose of the respondent having an Instagram account. Based on Figure 3, it can be said that Instagram content is in accordance with the needs of respondents in various aspects of their needs. This 
can be seen from the high blue diagrams on each need which indicate the number of respondents who rate the content displayed as needed.

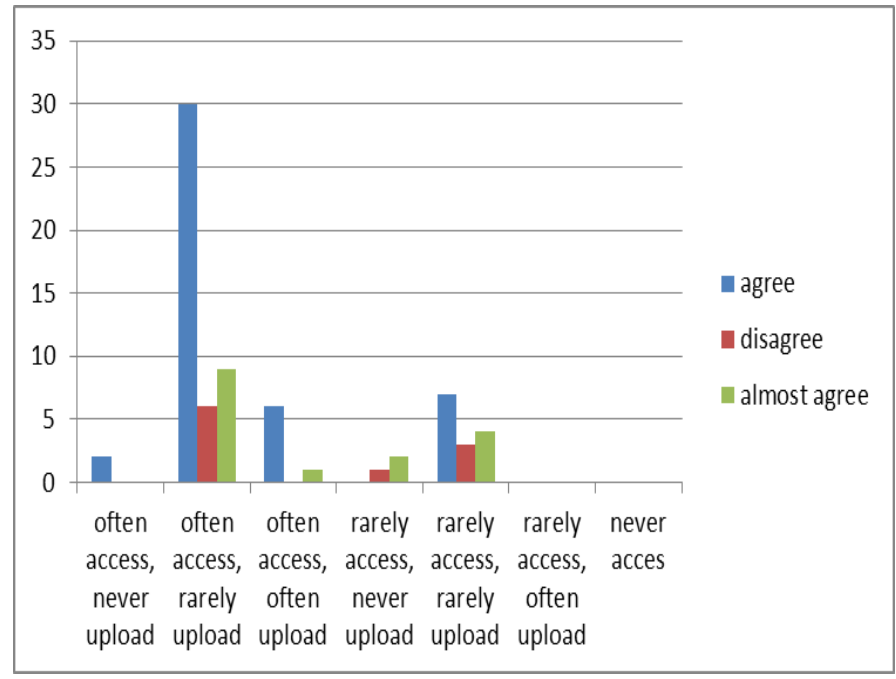

Fig. 4. Usage patterns based on conformity

Figure 4 is a bar diagram that shows the distribution of patterns of use of Instagram to suit the content and needs of respondents. The pattern of use in this analysis is divided into 7 groups, that is : often access and never upload, often access and rarely upload, often access and often upload, rarely access and never upload, rarely access and rarely upload, rarely access and rarely upload, and not ever access.

At the level of conformity agree, disagree and almost agree, the average respondent chooses frequent access patterns with diverse upload intensities. However, in the disagree of conformity, respondents do not have access patterns that are often and often upload. It can be identified that respondents are careful when using Instagram because Instagram content is deemed not accordance with their needs.

Based on Figure 4, it can be concluded that the majority of respondents with various levels of content suitability have the same usage pattern, which is often access and rarely upload. This can be seen from the more dominant red diagrams in each class of conformity.

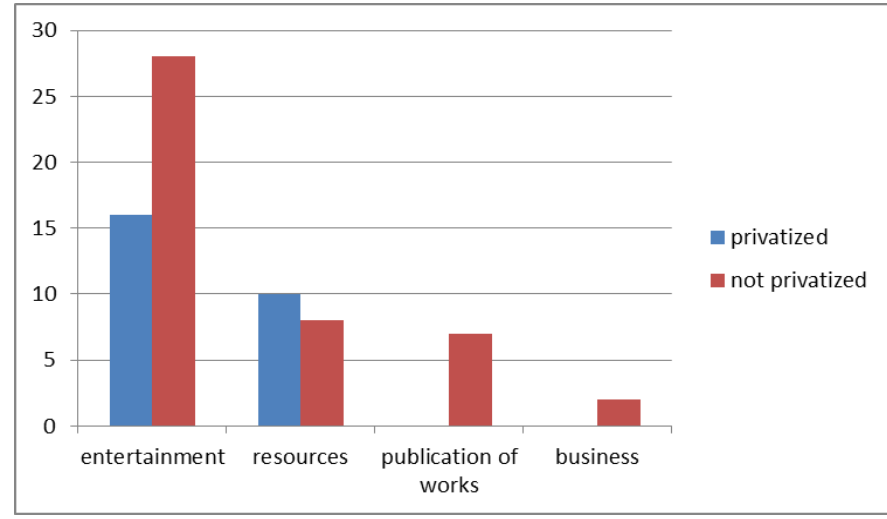

Fig. 5. Account security based on purpose
Figure 5 shows the relationship bar diagram using the privacy feature for the purpose of using Instagram. Based on Figure 5, it can be said that the purpose or needs of the use of Instagram affect the use of privacy features. This can be seen from the existence of differences in behavior patterns on the purpose of information sources. The purpose of information sources shows that most respondents data prefer to activate the privacy feature on their Instagram account. This pattern of behavior can be identified as a pattern of protection personal data based on perceptions of the purpose of using Instagram.

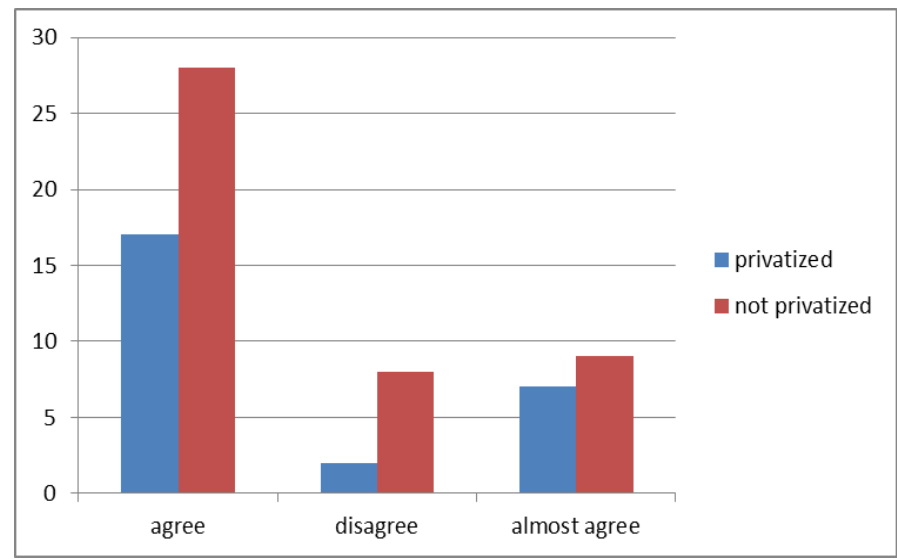

Fig. 6. Account security based on comformity

Figure 6 is a bar diagram that shows the behavior patterns of respondents who utilize the Instagram account privacy features based on the suitability of content with needs. Based on Figure 6, with different conformity criteria respondents have the same usage pattern that is not activating the privacy feature. From the agree category, the respondent did not activate the privacy feature, as well as in the disagree and almost agree category. This can be seen from the high red diagrams in each category. Based on Figure 6, it can be said that the level of content compatibility does not affect the use of privacy features.

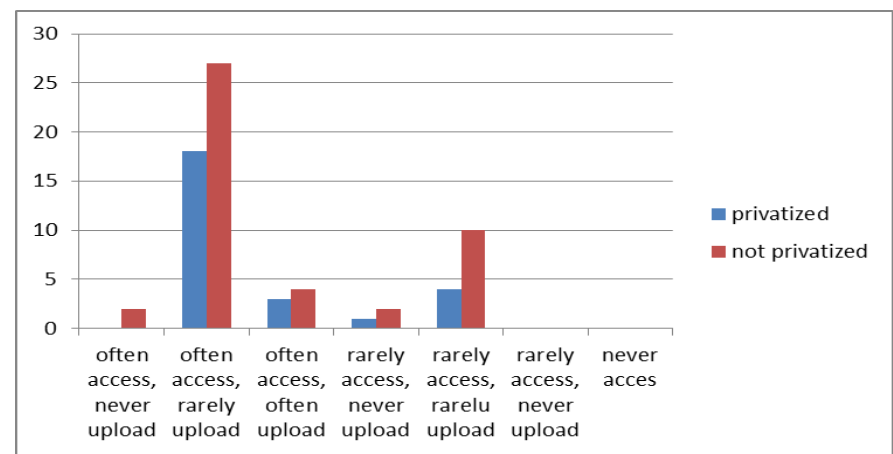

Fig. 7. Account security based on usage patterns

Figure 7 shows a bar diagram of the relationship using the privacy feature on the Instagram account with the intensity of use. The red diagram shows respondents who do not use of the privacy feature, while the blue diagram shows respondents who use the privacy feature. Based on Figure 7, it can be seen that from the varying intensity most respondents did not use the privacy feature on their intagram account. Can be 
concluded the intensity of the use of Instagram also does not affect the choice of the use of privacy features.

Based on the results of the study with 72 respondents and 7 supporting attributes, most of the respondents started using isntagram from the high school. This shows that respondents began to use when they entered the age that was considered to have been aware and could account for what was done while socializing the media.

The purpose of using Instagram from existing respondents' data is dominantly used as an entertainment medium with the most data, the second source of information, publication of works in the third place, and business in the last order.

The level of suitability of the goals and content of the Instagram in the four categories of usage objectives is fairly high. Minimal content mismatch occurs at the destination of information sources. Suitability with almost suitable categories is minimal in the purpose of publication of works.

The intensity of the use of Instagram is not affected by the suitability of the content or not. But on the suitability of content with inappropriate categories, respondents will reduce their interaction with instagram or it can be said to maintain more personal data. This can be seen from the absence of respondents who often choose, and often upload,

The use of privacy features on Instagram is not influenced by the suitability of content with purpose or intensity of use, but is influenced by the initial purpose of using Instagram. The initial purpose of using Instagram is the user's perception of the benefits of Instagram. Respondents with the purpose of Instagram as a medium of information sources tend to use the privacy features of their accounts.

\section{CONCLUSION}

The conclusion of the socio-cultural analysis study of the use of Instagram on students who live in the poor area shows that the respondents began using Instagram at the age that could be understood, understood, and could account for their actions when they were social media, namely the age range of high school and college. The purpose of using Instagram from the respondents' data is that students in the poor regions use Instagram as an entertainment medium. The suitability of the purpose of using the program with the content obtained does not affect the intensity of use but it affects the upload intensity, especially on the purpose of Instagram as a source of information. From these data the use of privacy features is not affected by the intensity of use and suitability of objectives with the content, but is influenced by the purpose of using the Instagram. The intensity of the use of Instagram starting from the frequency of use, upload and account privacy can be said as one of the personal branding efforts that aspect can improve user and audience communication. The content quality of the Instagram social media account, and the activity of users can have an impact on audience interest, which can increase personal branding. While for the use of privacy features can make curious audiences and start looking for user account data.

\section{References}

[1] H. Ting, W. W. P. Ming, E. C. de Run, and S. L. Y. Choo, "Beliefs about the use of Instagram: An exploratory study," Int. J. Bus. Innov., vol. 2, no. 2, pp. 15-31, 2015.

[2] M. Rahim, E. Erawan, and J. Alfando, "Motif Penggunaan Instagram Story (Studi Kasus pada Siswa Siswi Jurusan Multimedia di SMK Negeri 1 Samarinda)," J. Ilmu Komun. Univ. Mulawarman, vol. 6, no. 3, pp. 1-13, 2018.

[3] T. R. Ramadhanti, "Fenomena Pemanfaatan Instagram sebagai Media Personal Branding," Universitas Diponegoro, 2016.

[4] D. R. Indika and C. Jovita, "Media Sosial Instagram Sebagai Sarana Promosi Untuk Meningkatkan Minat Beli Konsumen," J. Bisnis Terap., vol. 1, no. 1, pp. 25-32, 2017.

[5] B. Bungin, Sosiologi Komunikasi. Jakarta: Kencana, 2006.

[6] S. Shuqair and P. Cragg, "The Immediate Impact of Instagram Posts on Changing the Viewers' Perceptions Towards Travel Destinations," in 1st International Conference on Advanced Research (ICAR-2017), 2017.

[7] P. Felita, C. Siahaja, V. Wijaya, G. Melisa, M. Chandra, and R. Dahesihsari, "Pemakaian Media Sosial dan Self Concept Pada Remaja," J. Ilm. Psikol. MANASA, vol. 5, no. 1, pp. 30-41, 2016.

[8] A. J. Al-Kandari, A. A. Al-Hunaiyyan, and R. Al-Hajri, "The Influence of Culture on Instagram Use," J. Adv. Inf. Technol., vol. 7, no. 1, pp. 5457, 2016.

[9] R. A. Manampiring, "Peranan Media Sosial Instagram dalam Interaksi Sosial Antar Siswa Sma Negeri I Manado (Studi Pada Jurusan IPA Angkatan 2012)," Acta Diurna Komun., vol. 4, no. 4, 2015.

[10] R. Sawyer and G.-M. Chen, "the impact of New Social Media on Intercultural Adaption," Intercult. Commun. Stud., vol. 21, no. 2, pp. 151-169, 2012. 